\title{
PEMERTAHANAN BAHASA SUNDA SEBAGAI WUJUD IDENTITAS MASYARAKAT DI DESA LUWUNG BATA, BREBES, JAWA TENGAH
}

\author{
Hesti Muliawati $^{1}$, Andi Sutisno ${ }^{2}$, Andika Dutha Bahari ${ }^{3}$, dan Bediyanto ${ }^{4}$ \\ Prodi Pendidikan Bahasa dan Sastra Indonesia, FKIP UGJ
}

\begin{abstract}
Abstrak
Bahasa tidak bisa dilepaskan dari penuturnya. Tanpa masyarakat penuturnya, bahasa tidak akan bisa bertahan atau akan punah. Dalam kehidupan masyarakat, bahasa selalu menempati posisi strategis sebagai alat atau media berkomunikasi. Di tengah-tengah masyarakat, pada kenyataannya bahasa tidak bersifat monolingua tetapi bisa beraneka dengan berbagai macam variasi bahasa di dalamnya. Hal ini juga yang terjadi pada masyarakat Desa Luwung Bata, Kabupaten Brebes. Kabupaten Brebes yang notabene secara geografis dan etnografis berada di wilayah Jawa Tengah dengan mayoritas pengguna bahasa Jawa, namun ada satu daerahnya yaitu Desa Luwung Bata yang berbahasa Sunda. Masyarakat di Desa Luwung Bata memiliki keunikan tersendiri sebab mereka berbahasa Sunda namun berada di tengah-tengah masyarakat yang mayoritasnya pengguna bahasa Jawa. Hal inilah yang membuat masyarakat Desa Luwung Bata memiliki tantangan sendiri dalam mempertahankan bahasa Sunda.
\end{abstract}

Kata Kunci: Variasi Bahasa, Bahasa dan Budaya, dan Pemertahanan Bahasa Sunda.

DOI: https://doi.org/10.31943/bi.v6i1.113

\section{How to Cite:}

Sutisno, A., Muliawati, H., Andika Dutha Bahari, \& Bediyanto. (2021). PEMERTAHANAN BAHASA SUNDA SEBAGAI WUJUD IDENTITAS MASYARAKAT DI DESA LUWUNG BATA, BREBES, JAWA TENGAH. Bahtera Indonesia; Jurnal Penelitian Bahasa Dan Sastra Indonesia , 6(1), 95-102. https://doi.org/10.31943/bi.v6i1.113

\section{PENDAHULUAN}

Bahasa daerah merupakan aset berharga bagi suatu bangsa. Akan tetapi, pAradigma masyarakat abad 21 menilai bahwa bahasa asing memiliki prestise lebih tinggi dibandingkan bahasa nasional dan bahasa daerah. Dengan kata lain, bahasa daerah berada di prioritas ketiga dalam penggunaanya setelah bahasa Nasional dan bahasa asing. Masyarakat lebih memilih menggunakan bahasa nasional dan bahasa asing dalam berkomunikasi. Penutur bahasa asing juga dinilai lebih berpendidikan dan memiliki strata sosial lebih tinggi, begitu pula sebaliknya, penutur bahasa daerah dinilai memiliki strata sosial di bawah penutur bahasa nasional dan bahasa asing.

Hal senada pernah diungkapkan oleh Gumperz (1982:101). Dalam satu 
wilayah dimungkinkan hidup beberapa variasi bahasa secara berdampingan sehingga bentuk interaksinya cenderung bersifat alih kode dan campur kode. Hal tersebut terjadi akibat masyarakat tuturnya berbahasa multilingual. Aktivitas komunikasi dalam masyarakat multilingual tidak lagi hanya berkiblat pada budaya setempat. Akibatnya, peran bahasa daerah seperti bahasa jawa, sunda, dan lainnya tidak menjadi priorita utama dalam komunikasi sehari-hari. Bahasa jawa hanya hadir dalam komunikasi sosial terbatas, seperti keluarga dan masyarakat seetnis.

Bahasa yang dimiliki oleh suatu masyarakat tutur dalam khazanah bahasanya selalu memiliki variasi. Hal itu disebabkan oleh kenyataan bahwa bahasa yang hidup dalam masyarakat selalu digunakan dalam peran-peran sosial para penuturnya. Peran-peran sosial berkaitan dengan berbagai aspek sosial psikologis yang kemudian di rinci dalam bentuk komponen-komponen tutur (Poedjosoedarmono 1982:3). Adanya fenomena pemakaian variasi bahasa dalam masyarakat tutur dikontrol oleh faktorfaktor sosial, budaya, dan situasional. (Kartomihardjo 1981: Fasold:1984 Hudson:1996) disisi lain, bahasa daerah merupakan kekayaan suatu masyarakat yang berdilkari dalam kehidupan. Bahasa daerah memuat kearifan suatu masyarakat pula. Ada niali-nilai kebudayaan yang terkandung dalam bahasa daerah. Oleh sebab itu, bahasa daerah dapat dikatakan sebagai cerminan suatu masyarakat tuturnya. Bahasa daerah warisan yang luhur bagi masyarakat.

Fenomena kebahasaan ini terjadi pada masyarakat Desa Luwung Bata, Kecamatan Tanjung, Kota Brebes, Provinsi Jawa Tengah yang hidup berbeda dari sekitar lingkungan lainnya diwujudkan dari penggunaan bahasa Sunda yang merupakan kebudayaan turun temurun dari sesepuh. Berdasarkan informasi dari kepala desa masyarakat
Desa Luwung Bata yang tetap mempertahankan bahasa Sunda terdapat di Rt. 01 s.d. 06 Rw.01 dan Rt.02 s.d. 06 Rw. 02. Masyarakat tersebut dalam kehidupan sehari-hari menggunakan bahasa Sunda, sedangkan masyarakat lainnya menggunakan bahasa Jawa. Jika mereka berkomunikasi dengan masyarakat yang mengunakan bahasa Jawa maka terjadi komunikasi alih kode menggunakan bahasa Jawa sesuai pada lawan bicara. Maka dari itu masyarakat Luwung Bata dapat dikategorikan dwibahasawan.

Keterkaitan antara bahasa dan kebudayaan masyarakat di desa Luwung Bata, Brebes juga dikaitkan dengan asalusul sesepuh. Sejarah Asal muasal disebutnya Desa Luwungbata menurut para sesepuh Desa adalah bahwa sebelum menjadi sebuah desa merupakan sebuah hutan (dalam bahasa sunda disebut "Leuweung") yang banyak ditumbuhi pepohonan dan rumput ilalang. Berdasarkan later belakang di atas, penulis ingi mengetahui sejauh mana pemertahanan bahasa pada masyarakat Desa Luwung Bata tersebut. Oleh karena itu penulis akan mengadakan penelitian dengan judul "Pemertahanan Bahasa sebagai Wujud Identitas Masyarakat di Desa Luwung Bata, Brebes, Jawa Tengah".

\section{KAJIAN TEORETIS}

Pemertahanan bahasa (language mainantance) berkaitan dengan masalah sikap atau penilaian terhadap suatu bahasa untuk tetap menggunakan bahasa tersebut di tengah-tengah bahasa lainnya. Kridalaksana mengartikan " usaha agar suatu bahasa tetap dipakai dan dihargai", terutama sebagai identitas kelompok dalam masyarakat bahasa yang bersangkutan melalui pengajaran, kesusastraan, media massa dan lain-lain.

Pemertahanan bahasa adalah sebagai upaya yang disengaja antara lain untuk (1) mewujudkan diversitas kultural, 
(2) memelihara identitas etnis, memungkinkan adaptabilitas sosial, (4) secara psikologis menambah rasa aman bagi anak, dan (5) meningkatkan kepekatan linguistis

Dalam pemertananan bahasa, komunitas secara kolektif memutuskan untuk terus menggunakan bahasa tersebut atau bahasa itu telah digunakan secara tradisional. Ketika sebuah komunitas tutur mulai memilih bahasa baru dalam daerah sebelumnya dicadangkan untuk yang lama, ini merupakan tanda bahwa pergeseran bahasa sedang berlangsung. Apabila komunitas tutur adalah monolingual dan tidak memperoleh bahasa lain secara kolektif, maka mereka jelas mempertahankan pola penggunaan bahasa mereka. Pemertahanan bagaimanapun sering merupakan karaktersitik dari komunitas dwibahasa atau juga multibahasa. Hal ini hanya terjadi ketika komunitas mengalami diglosia. Dalam kata lain adalah bahwa komunitas multibahasa bahasa-bahasa menjaga setiap cadangan untuk daerah tertentu dengan perambahan sangat sedikit monolingual di daerah yang lain.

Banyak pakar yang memang menyatakan bahwa perilaku belum tentu menujukkan sikap.

Terdapat tiga ciri sikap bahasa sebagai berikut:

a. Kesetiaan bahasa (language loyalty) yang mendorong masyarakat suatu bahasa mempertahankan bahasanya, dan apabila perlu mencegah adanya pengaruh bahasa lain.

b. Kebanggaan bahasa (language pride) yang mendorong orang mengembangkan bahasanya dan menggunakan sebagai lambang identitas dan kesatuan masyarakat.

c. Kesadaran adanya norma bahasa (awareness of the norm) yang mendorong orang menggunakan bahasanya dengan cermat dan santun dan merupakan faktor yang sangat besar pengaruhnya terhadap perbuatan yaitu kegiatan kegunaan bahasa (language use).

Anderson (Chaer, 2004: 151) membagi sikap atas dua macam yaitu 1) sikap kebahasaan dan 2) sikap nonkebahasaan, sepertai sikap politik, sikap sosial, sikap estetis dan sikap keagamaan, menyangkut keyakinan atau kognisi mengenai bahasa. Sikap bahasa adalah tata keyakinan atau kognisi yang relatif berjangka panjang, sebagian mengenai bahasa, mengenai objek bahasa, yang memberikan kecenderungan kepada seseorang untuk bereaksi dengan cara tertentu yang disenanginya.

Pemilihan bahasa (language choice) lazimnya lahir akibat penggunaan bahasa dalam suatu masyarakat bilingual (dwibahasa) dan multilingual (multibahasa). Dalam pemilihan bahasa, kekeliruan dalam peristiwa pemilihan lbahasa atau ragam bahasa yang cocok dengan situasi komunikasi itu tidak dapat dihindari, dan kekeliruan tersebut dapat berakibat kerugian bagi peserta komunikasi.

Pemilihan bahasa menurut Fasold (1984: 180) adalah memilih "sebuah bahasa secara keseluruhan" dalam suatu komunikasi. Dalam masyarakat multibahasa tersedia berbagai kode, baik berupa bahasa, dialek, variasi dan gaya untuk digunakan dalam interaksi sosial. Berbrda halnya dengan pendapat Kartomihardjo lebih suka mempergunakan istilah ragam sebagai padanan dari style. Dengan tersedianya kode-kode itu, anggota masyarakat akan memilih kode yang tersedia sesuai dengan faktor-faktor yang mempengaruhinya. Dalam interaksi sosial sehari-hari, anggota masyarakt secara konstant mengubah variasi penggunaan bahasanya.

Dalam sebuah negara, berlaku penggunaan dwibahasa dan setiap individu mengetahui lebih dari satu bahasa. Dalam 
masyarakat bilingual atau multilingual masyarakat harus memilih bahasa mana yang harus digunakan. Dalam hal pilihan ini ada tiga jenis pilihan yang digunakan.

1) Alih kode, yaitu menggunakan suatu bahasa pada suatu keperluan dan bahasa lain pada keprluan yang lain.

2) Campur kode, yaitu menggunakan bahasa tertentu dengan dicampur sebagian dari bahasa lain.

3) Dengan memilih variasi bahasa yang sama.

Ketiga pilihan ini dapat dilakukan dengan mudah, tetapi malah terkandung sulit untuk dilakukan karena kesulitan membedaakan antara alih kode dan campur kode. Seseorang yang melakukan pemilihan bahasa dalam komunikasinya sebenarnya sdang menerapkan kompetensi kommunikatifnya, atau sedang menunjukkan performasi komunikatifnya.

Antropologi merupkan kajian yang mempelajari manusia dengan kebudayaan Secara menyeluruh, di satu pihak manuisa juga adalh pencipta kebudayaan, di pihak lain kebudayaan yang menciptakan manusia sesuia dengan lingkungan. Dalam kebudayaan bahasa menduduki tempat yang unik dan terhormat. Selain sebagai unsure kebudaayan, bahasa juga berfungsi sebagai sarana terpenting dalam pewarisan ,pengembangan dan penyebarlusan kebudayaan.

Antropologi juga merupakan lingusitik salah satu cabang lingusitik makro yang menelaah hubungan antara bahsa dan kebudayaan terutma untuk mengamati bagaimana bahasa di gunakan dalam kehidupan sehar-hari sebagai alat dalam tindakan bermasyarakat. Kajian ini juga disebut enolinguistik menelaah bahasa bukan hanya dari setruktur semata tapi lebih pada fungsi dan pemakianya dalam konteks sosial budaya.

Masayarakat bahasa merupakan sekumpulan manusia yang menggunkan sistem sayarat bahasa yang sama Bloomfield oleh para ahli sosilinguistik dianggap terlalu sempit karena setiap orang menguasai dan menggunakan lebih dari satu bahasa (Nababan, 1991:5) Masyrakat bahasa disebut juga masyarakat tutur. Dalam hal ini masyarakat tutur pada hakekatnya bukan hanya kelompok orang yang mengguanakan bahsa yang sama melainkan kelompok orang yang mempunyai norma yang sama dalam mengguankan bentuk bahasa. Dalam masyarakat tutur, konsep yang paling mendasar perasan menggunakan tutur yang sama antara penutur. Jika demikian, maka kedua dialek yang secara linguistik merupakan satu bahsa dianggap dua dari masyarakat tutur yang berbeda. Dengan demikian, pada dasarnya bahasa dan masyarakat sangat erat kaitanya sangat erat. Antara keduanya memiliki hubungan timbal balik. Ada beberapa aspeknya yaitu hubungan antara bahasa tertentu yang disebut variasi, ragam, atau dialek dengan penggunaanya dengan untuk fungsi-fungsi tertentu di masyarakat.

\section{METODE PENELITIAN}

Metode yang digunakan dalam penelitian ini adalah menggunakan metode deskriptif kualitatif dengan kajian antropolinguistik. Bogdan dan Taylor dalam Moleong (2010, hlm. 4) mengemukakan bahwa penelitian kualitatif adalah prosedur penelitian yang menghasilkan data deskriptif berupa katakata tertulis atau lisan dari orang-orang dan perilaku yang dapat diamati. Dengan demikian, hal ini peneliti bertujuan untuk mengetahui asal muasal atau sejarah bahasa dan kebudayaan desa Luwung Bata, Brebes. Yang memiliki suatu keunikan pada penggunaan bahasa Sunda di tengahtengah masyarakat berbahasa Jawa. Adapun metode yang digunakan dalam penelitian ini adalah dengan menggunakan metode observasi dan wawancara. Sebagai suatu hal untuk membantu menemukan 
suatu fakta atau data pada faktor-faktor yang mempengaruhi hal tersebut dan akan menjadi jawaban dari penelitian yang sedang diteliti.

Teknik yang digunakan pada penelitian kali ini adalah dengan menggunakan teknik simak libat cakap, karena si peneliti melakukan dengan cara berpartisipasi sambil menyimak, berpartisipasi dalam pembicaraan, dan menyimak pembicaraan. Dalam hal ini, si peneliti terlibat langsung dalam dialog. Selain itu, peneliti juga menggunakan teknik catat, yakni semua data-data yang sudah diberikan oleh informan dan pertanyaan angket yang dapat kita catat sebagai sumber data yang kita jadikan bahan isi laporan.

Teknik yang digunakan pada peneliti untuk mengumpulkan data penelitian adalah dengan teknik wawancara dan observasi pada masyarakat di Desa Luwung Bata kecamatan Tanjung kabupaten Brebes. Pengumpulan data penelitian ini guna bertujuan untuk mengetahui sejauh mana pengetahuan sejarah atau latar belakang mengenai bahasa dan kebudayaan mereka yang dianut, serta mengetahui asal muasal penggunaan bahasa Sunda di tengahtengah masyarakat berbahasa Jawa.

\section{PEMBAHASAN}

Bahasa tidak bisa dilepaskan dari penuturnya. Tanpa masyarakat penuturnya, bahasa tidak akan bisa bertahan atau akan punah. Masyarakat di Desa Luwung Bata memiliki keunikan tersendiri sebab mereka berbahasa Sunda namun berada di tengahtengah masyarakat yang mayoritasnya pengguna bahasa Jawa. Hal inilah yang membuat masyarakat Desa Luwung Bata memiliki tantangan sendiri dalam mempertahankan bahasa Sunda.

\section{Variasi Bahasa Masyarakat Desa Luwung Bata.}

Situasi masyarakat Desa Luwung Bata Kecamatan Tanjung, Kabupaten Brebes, Provinsi Jawa Tengah yang hidup berbeda dari lingkungan sekitarnya (masyarakat Jawa Tengah pada umumnya) tampak pada penggunaan bahasa Sunda yang merupakan kebudayaan turun temurun dari sesepuh. Berdasarkan informasi dari kepala desa masyarakat Luwung Bata yang tetap mempertahankan bahasa Sunda terdapat di Rt. 01 s.d. 06 Rw.01 dan Rt.02 s.d. 06 Rw. 02. Masyarakat tersebut dalam kehidupan sehari-hari menggunakan bahasa Sunda, sedangkan masyarakat lainnya menggunakan bahasa Jawa. Jika mereka berkomunikasi dengan masyarakat yang mengunakan bahasa Jawa maka terjadi komunikasi alih kode menggunakan bahasa Jawa sesuai pada lawan bicara. Maka dari itu masyarakat Luwung Bata dapat dikategorikan dwibahasawan.

Kedwibahasaan bahasa di masyarakat Desa Luwung Bata membuat masyarakatnya mampu berkomunikasi sesuai dengan situasi tuturan dan lawan tutur. Misalnya, di Rw. 02 hanya Rt. 02 s.d. Rt. 06 yang berbahasa Sunda sedangkan Rt. 01-nya berbahasa Jawa. Secara geografis, mereka sangat dekat namun secara bahasa ada "jarak" dalam berbahasa. Akan tetapi, hal tersebut tidak lantas menjadikan masyarakat di Rw. 02 mengalami kesulitan dalam berkomunikasi. Dalam perjalanannya, komunikasi yang terjalin antarmasyarakat dalam satu Rw. tersebut berjalan dengan baik. Mereka mampu menempatkan diri sesuai dengan situasi tutur ketika berkomunikasi. Tentu saja, situasi seperti itu menjadikan masyarakat Desa Luwung Bata memiliki kekayaan dalam berbahasa.

\section{Keterkaitan Antara Bahasa dan Budaya Masyarakat Desa Luwung Bata}

Keterkaitan antara bahasa dan kebudayaan masyarakat di Desa Luwung

Fakultas Keguruan dan Ilmu Pendidikan 
Bata, Brebes juga dikaitkan dengan asalusul sesepuh. Sejarah asal muasal disebutnya Desa Luwung Bata menurut para sesepuh desa adalah bahwa sebelum menjadi sebuah desa merupakan sebuah hutan (dalam bahasa sunda disebut "Leuweung") yang banyak ditumbuhi pepohonan dan rumput ilalang. Pada suatu ketika, datanglah seseorang bersuku Sunda berasal dari wilayah yang sekarang disebut Luragung yang termasuk dalam wilayah Kabupaten Kuningan. Seorang yang bersuku Sunda tersebut menetap dan akhirnya menjadi sesepuh dan panutan di Desa Luwung Bata. Kemudian setelah sekian waktu datanglah seseorang yang konon masih keturunan sunan dari wilayah Cirebon yang mempunyai rencana untuk membangun keraton di wilayah Cirebon itu, kemudian di Leuweung (hutan) tersebut segera dilaksanakanlah pembuatan batu bata yang diperuntukan untuk pembangunan Kesultanan Kasepuhan Cirebon pada waktu itu.

Lain pula dengan asal muasal dari Pedukuhan Danareja yang masih termasuk dalam wilayah Desa Luwungbata, dimana para pendiri Pedukuhan Danareja konon adalah bekas laskar Pangeran Diponegoro dalam Perang Jawa. Setelah Pangeran Diponegoro tertangkap oleh tipu muslihat Belanda dalam Perjanjian Giyanti, beberapa laskar yang tersisa memilih menetap di daerah ini hingga membuka hutan baru guna dijadikan sebuah pemukiman dengan konsep Jawa Islami yang masih kental saat itu, inilah yang menyebabkan dikemudian hari bahasa yang digunakan di pedukuhan ini berbeda dengan di desa induknya. Beberapa makam tetrua pun masih terawat dengan baik di Pedukuhan Danareja berikut dengan segenap adat istiadat maupun kebiasaan turun temurun yang masih dijaga dan dilestarikan oleh penduduk diantaranya Adat Sedekah Bumi dan kebiasaan lainnya. Begitulah sepenggal sejarah Desa Luwungbata yang diterima dari para sesepuh Desa. Sehingga ada masyarakat Desa Luwung Bata yang hingga saat ini mempertahankan bahasa Sunda turun temurun dari sesepuh.

Berdasarkan latar belakang sejarah tersebut, dapat diduga bahwa sebagian masyarakat yang berada Desa Luwung Bata berasal dari keturunan sesepuh yang menggunakan bahasa Sunda. Dengan demikian masyarakatnya menggunakan bahasa Sunda. Selain itu, hal ini diperkuat dengan hasil analisis data melalui angket yang diperoleh dari masyarakat Rt. 01 s.d. 06 Rw.01 dan Rt.02 s.d. 06 Rw. 02 Desa Luwung Bata memang benar adanya berkomunikasi menggunakan bahasa Sunda dalam kesehariannya. Jadi, sangat jelas dikatakan bahwa masyarakat Luwung Bata suku Sunda di tengah-tengah masyarakat Jawa. Akan tetapi masyarakatnya juga hampir $85 \%$ mengerti bahasa Jawa, tetapi jarang digunakan. Terkecuali untuk berkomunikasi dengan tetangga desa yang menggunakan bahasa Jawa. Berkaitan dengan keunikan variasi bahasa tersebut, terdapat keterkaitan anatara bahasa dan kebudayaan mengenai asal mulanya masyarakat desa Luwung Bata. Jadi, sudah jelas bahwa awal mulanya masyarakat Luwung Bata sebagian besar merupakan keturunan sesepuh suku Sunda yang menetap disana dan pada akhirnya mempunyai masyarakat tutur tersendiri yang berbeda dengan masyarakat tutur di sekitarnya. Bahasa dan kebudayaan memang tidak dapat dipisahkan karena bahasa dan kebudayaan merupakan dua sistem yang melekat pada manusia. Kebudayaan itu sistem yang mengatur manusia, maka bahasa adalah suatu sistem yang berfungsi sebagai sarana interaksi kebudayaan itu sendiri.

\section{Sikap Masyarakat Desa Luwung Bata dalam Mempertahankan Bahasa Sunda}

Cara dan sikap masyarakat Luwung Bata mempertahankan dan melestarikan 
bahasanya dengan cara memperkenalkan dan mengajarkan bahasa pertama (bahasaa ibu) kepada anaknya menggunakan bahasa Sunda, walaupun mereka menikah tidak dengan orang satu desa tetapi mereka tetap mempertahankan bahasa sesepuhnya (bahada Sunda) walaupun bahasa Sunda yang mereka gunakan merupakan bahasa Sunda kasar. Meskipun mereka dikelilingi oleh orang-orang yang menggunakan bahasa Jawa atau bahasa Indonesia, tetapi mereka dapat berkomunikasi dengan baik dan dapat menyesuaikan dengan lawan bicaranya. Jadi, mereka mempunyai kelebihan menguasai lebih dari dua bahasa yaitu kedwikebahasaawan dan multilingualisme.

Ada beberapa masyarakat yang mengatakan bahwa mereka akan tetap menjaga dan bangga terhadap kebudayaan dan bahasa mereka, karena siapa lagi yang akan bangga dan mempertahankan selain diri meraka dan masyarakat Luwung Bata tersebut. Masyarakat Luwung Bata juga merasa bahasa Sunda merupakan sesuatu yang penting dan kebanggaan masyarakat tersebut, karena bahasa Sunda merupakan bagian dari jati diri asal usul dari mana mereka berasal dan merupakan kebudayaan yang harus mereka lestarikan.

\section{SIMPULAN}

Masyarakat

Indonesia

dikategorikan masyarakat multibahasawan atau multilingualisme dan kedwibahasawan. Hal ini terlihat dari penggunaan berkomunikasi masyarakat yang beragam. Dalam kesehariannya masyarakat menggunakan bahasa ibu (frist language) sebagai alat komunikasi dan bahasa Indonesia sebagai bahasa ke dua (second language ) yang digunakan dalam situasi resmi.

Berdasarkan keanekaragaman tersebut di desa luwung bata kecamatan tanjung kota brebes provinsi jawa tengah yang mayoritas masyarakatnya menggunakan bahasa "Sunda" sedangkan masyarakat diluar desa luwung bata menggunakan bahasa "Jawa", sehingga di desa luwung bata memiliki keunikan bahasa tersendiri karna desa tersebut terus mempertahankan kebudayan turun temurun dari nenek moyang yang berasal dari kecamatan Luragung kabupaten Kuningan.

Hasil analisis data menyimpulkan bahwa pada setiap RT nya yakni : RT 0106 dan RW 01-02 masyarakat tersebut dalam kehidupan sehari-hari menggunakan bahasa Sunda, sedangkan masyarakat lainnya mengunakan bahasa Jawa. Jika mereka berkomunikasi dengan masyarakat sekitar yang mengunakan bahasa Jawa maka terjadi komunikasi alih kode, menggunakan bahasa jawa sesuai lawan bicara maka dari itu masyarakat Luwung Bata dikatagorikan masyarakat yang dwibahasawan.

Berdasarkan hasil wawancara dengan beberapa warga dan para sesepuh di Desa Luwung Bata, Jawa Tengah memiliki variasi sendiri. Ini juga sekaitan dengan sejarah penamaan nama Desa Luwung Bata. Pada awalnya Desa Luwung Bata bermula dari sebuah "hutan" dalam bahas a Sunda disebut (leuweng) yang banyak ditumbuhi pepohonan dan rumput ilalang. Bisa jadi juga penamaan Luwung berasal dari kata Leweung.

Pada suatu ketika, datanglah seseorang bersuku Sunda berasal dari wilayah yang sekarang disebut Luragung. Yang termasuk dalam wilayah Kabupaten Kuningan. Seseorang yang bersuku Sunda tersebut menetap dan akhirnya menjadi sesepuh dan panutan di Desa Luwung Bata. Berdasarkan latar belakang kejadian tersebut maka masyarakat Desa Luwung Bata menggunakan bahasa Sunda. Berkaitan dengan keunikan variasi bahasa tersebut, terdapat keterkaitan antara bahasa dan kebudayaan. Bahasa dan kebudayaan memang tidak dapat dipisahkan,karena bahasa merupakan salah satu bagian dari unsur kebudayaan. Cara dan sikap 
masyarakat Luwung Bata mempertahankan dan melestarikan bahasanya dengan cara memperkenalkan dan mengajarkan bahasa pertama (bahasaa ibu) kepada anaknya menggunakan bahasa Sunda, walaupun mereka menikah tidak dengan orang satu desa, tetapi mereka tetap mempertahankan bahasa sesepuhnya (bahada Sunda) walaupun bahasa Sunda yang mereka gunakan merupakan bahasa Sunda kasar. Meskipun mereka dikelilingi oleh orang-orang yang menggunakan bahasa Jawa atau bahasa Indonesia, tetapi mereka dapat berkomunikasi dengan baik dan dapat menyesuaikan dengan lawan bicaranya. Jadi, mereka mempunyai kelebihan menguasai lebih dari dua bahasa yaitu disebut dengan dwikebahasawan bahkan multibahasawan.

Beberapa masyarakat Desa Luwung Bata juga mengatakan bahwa mereka akan tetap menjaga dan bangga terhadap bahasa yang digunakan untuk berkomunikasi yaitu bahasa Sunda aHal ini menjadi salah satu bukti bahwa masyarakat Desa Luwung Bata mempertahankan bahasa dan kebudayaannya sebagai wujud dan jati diri asal usul dari mana mereka berasal dan merupakan kebudayaan yang harus mereka lestarikan.

\section{DAFTAR PUSTAKA}

Aminudin. $1990 . \quad$ Pengembangan Penelitian Kulaitatif dalam Bidang Bahasa dan Sastra. Malang: YA3 Malang.

Aslinda dan Syafyahya, Leni. 2007. Pengantar Sosiolinguistik. Bandung: PT Refika Aditama.
Campbel, dkk. 2006. Metode Praktis Pembelajaran Berbasis Multiple Intelligence. Depok: Intuisi Press.

Chaer, Abdul. 2003. Psikolinguistik: Kajian Teoretik. Jakarta: Rieneka Cipta.

Chaer, Abdul dan Agustina, Leoni. 2004. Sosiolinguistik: Perkenalan Awal. Jakarta: PT Rineka Cipta.

Chomsky, N. 1965. Aspects of The Theory of Syntax. Cambridge: MA, MIT Press.

Ddardjowidjojo, Soenjono. Psikolinguistik: Pengantar Pemahaman Bahasa Manusia. Jakarta: Yayasan Obor.

Fasold, Ralp. 2001. Sosiolinguistik of Society. New York: Basil Blackwell. Fromkin, Victoria dan College.

Hudson, R.A. 1980. Sociolinguistics. London: Cambridge University Press.

Lambert, W.E.A. Social Psichologhy of Bilingualism. Journal of Social Issues 23.

Sahertian, Debby. 2008. Kamus Bahasa Gaul (Kamasutra Bahasa Gaul). Jakarta: Pustaka Sinar Harapan.

Sudaryanto. 1993. Metode dan Aneka Teknik Analisis Bahasa, Pengantar Penelitian Wahana Kebudayaan Secara Linguistik. Yogyakarta: Duta Wacana University Press.

Sudaryanto. 2009. Pengajaran Kdwibahasaan. Bandung: Pustaka Pelajar. 